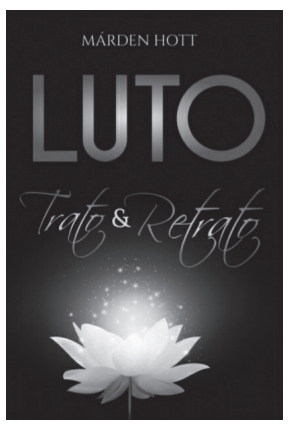

\title{
Hott M. Luto: Trato \& Retrato
}

\author{
Márden Hott
}

DOI: 10.1590/0103-1104202012626

A 'PERTURBAC̣Ão de LUTO COMPLEXo PERSISTENTE', sugerida no apêndice do 'Manual Diagnóstico e Estatístico de Transtornos Mentais' (DSM5), publicado pela Associação Americana de Psiquiatria, em 2014, e referência mundial para as questões relacionadas à saúde mental, indica a necessidade de estudos consistentes sobre o estado de enlutamento complicado e tem causado polêmicas conceituais, dividindo opiniões. Mas há o consenso de que esse infortúnio pode atingir qualquer pessoa, em diversos momentos, pois todos já passaram, estão passando ou irão passar pelo luto, complexo ou não.

Há defensores do enlutamento como quadro patológico quando a tônica sintomatológica dos sentimentos de perda e a temporalidade largamente estendida dificultam o balizamento da dor, podendo levar a sérias consequências na saúde física e emocional da pessoa nessa condição, inclusive induzindo o portador ao último passo (o suicídio), requerendo, assim, diagnóstico e intervenções precoces. Por outro lado, há profissionais e pesquisadores da psique que considerem o luto como um sentimento normal, de determinação exclusivamente individual e que cada qual manifesta em seu tempo, sem necessidade de intervenções. Simples assim.

No entanto, 'Luto: Trato \& Retrato'1, obra lançada em abril de 2020, contempla, para além do percurso individual da escritora no contexto do processo de morte e morrer, diversas e adversas situações de enlutados e estratégias para o enfrentamento da dor, com foco na saúde mental alicerçada pela espiritualidade. O discurso é realista, emocionalmente contundente, desprovido de máscaras que encobrem, inibem e/ou censuram aqueles que por vezes se sentem acuados e sem direcionamento congruente para a resolutividade da questão. Portanto, para muitos afetados pelo enlutamento, não é tão simples assim.

O que chama a atenção na produção literária é o discurso da autora, que, mesmo se envolvendo com pesquisas acadêmicas sobre o luto, viu-se profundamente atingida por ele, reforçando a hipótese do despreparo, ainda que se acredite estar instrumentalizado para o enfrentamento do fato. Para além, o transtorno proveniente do enlutamento complicado é abordado não somente como problema pessoal, mas, também, como uma questão familiar 
O capítulo inicial do livro vai diretamente ao ponto, trazendo a conclusão nas primeiras páginas, que reforçam a teoria de históricos pesquisadores do luto: os seres humanos, apesar de terem como única certeza a inevitabilidade da morte, não estão preparados para compreender a naturalidade do único fenômeno que sabidamente é universal e, na maioria das vezes, de instante imprevisível. $\mathrm{O}$ medo da finitude está arraigado às questões culturais ocidentais e especialmente à brasileira, visto que ignorar, permear de hesitação ou negar o porvir faz parte do senso comum desta população. Não obstante, o instinto de preservação e sobrevivência é natural em todo ser vivo.

Contudo, os capítulos sequentes abordam e retomam os pensamentos de negatividade que afligem o enlutado, os intermináveis inquéritos sobre a morte e revela uma questão fundamental para que se tente entender o turbilhão de emoções que envolve as mais íntimas carências de solução: o desvencilhar da culpa, mesmo que ela não seja evidenciada pelo evento em si, ou conscientemente cogitada. O pensar em ter feito mais e melhor pelo ente querido que atingiu sua finitude biológica talvez seja uma das principais chaves para abrir as portas que aprisionam as pessoas no problema.

Outra questão relevante é a interrupção do ciclo vital, quando o ideário do processo de nascer, crescer, reproduzir, envelhecer e morrer é interrompido por óbitos de infantes ou adolescentes. Mas não se atém somente a isso, pois tanto quanto nas fases da adultez ou senescência, por meio de patologias potencialmente fatais, acidentes, homicídios e autoextermínio, o enlutamento patológico também se constrói. Ao afirmar que 'dor é dor', os fatores que conduziram ao desfecho final, apesar de darem significado ao enredo, perdem potencialidade ao considerar o tipo de vínculo (ou a falta dele) como o principal marcador do desarranjo do luto. A questão sempre será inusitada, ainda que seja recorrente, pois a qualidade do laço (des)construído é o verdadeiro fator de risco, traduzindo a particularidade das relações humanas.

Em contrapartida, a alegação dá veemência na positividade para a busca do triunfo sobre a dor por meio da espiritualidade e a tentativa, embora às vezes frustrada, de desvendar os mistérios que envolvem a morte, não obstante a imperativa necessidade - em muitos casos - do auxílio médico e/ou psicológico para se desvencilhar do transtorno. A Organização Mundial da Saúde, ao definir 'saúde', prevê a inserção da espiritualidade nos cuidados às pessoas em sofrimento, não apenas físico, mas também psíquico, ao afirmar que estar saudável não é apenas se eximir da doença, mas, sim, deter o bem- estar físico, social e emocional (espiritual).

Nesses termos, o encontro com a crença e a fé, independentemente da religiosidade - embora a ênfase seja dada ao espiritismo e aos seus pilares: ciência, filosofia e religião, bem como às suas vertentes: imortalidade da alma e comunicabilidade dos espíritos, registrada através da mediunidade -, demonstra o potencial consolador da adesão ou da descoberta da possibilidade de conexão com o divino, entretanto, livre de proselitismo. Assim, a espiritualidade se torna elemento essencial para vencer as fragilidades emocionais. O desenhar do inicial panorama obscuro do luto complicado e, no decorrer, a sinalização gradativa das medidas de elucidação do óbice, ademais, agregam no compartilhamento de experiências com os pares, outro potente recurso de alívio. O 'compreender e o ser compreendido' notabiliza o valor e a magnitude da empatia, que, mesmo não sendo curativa, funciona eficazmente como medida paliativa.

Claramente, a argumentação chama a atenção dos enlutados e daqueles que lidam com o luto, para o entendimento de que estes não estão e não precisam estar sozinhos nessa trajetória árdua. Com o auxílio adequado, mediante o suporte de profissionais da saúde (competentes e humanizados), o 
fortalecimento das relações interpessoais e o estreitamento de afinidade com a espiritualidade que melhor aprouver, é possível retomar a vida, possivelmente com a mesma qualidade de antes ou similar, combatendo e superando os obstáculos que antes eram vistos como instransponíveis.

\section{Colaboradora}

Hott M (0000-0002-2791-8677)* é responsável pela elaboração do manuscrito.

\section{Referência}

1. Hott M. Luto: Trato \& Retrato. Santa Luzia: Chico Xavier; 2020.

Recebido em 29/04/2020

Aprovado em 29/06/2020

Conflito de interesses: inexistente

*Orcid (Open Researcher and Contributor ID). 